\title{
Angolan Cymbopogon citratus used for therapeutic benefits: Nutritional composition and influence of solvents in phytochemicals content and antioxidant activity of leaf extracts
}

Marta O. Soares, Rita C. Alves, Pedro C. Pires, M. Beatriz P.P. Oliveira, Ana F. Vinha

\begin{abstract}
Folk medicine is a relevant and effective part of indigenous healthcare systems which are, in practice, totally dependent on traditional healers. An outstanding coincidence between indigenous medicinal plant uses and scientifically proved pharmacological properties of several phytochemicals has been observed along the years.

This work focused on the leaves of a medicinal plant traditionally used for therapeutic benefits (Ango- lan Cymbopogon citratus), in order to evaluate their nutritional value. The bioactive phytochemical com-position and antioxidant activity of leaf extracts prepared with different solvents (water, methanol and ethanol) were also evaluated.

The plant leaves contained rv60\% of carbohydrates, protein (rv20\%), fat (rv5\%), ash (rv4\%) and moisture (rv9\%). The phytochemicals screening revealed the presence of tannins, flavonoids, and terpenoids in all extracts. Methanolic extracts also contained alkaloids and steroids. Several methods were used to eval- uate total antioxidant capacity of the different extracts (DPPH; NO; and H2O2 scavenging assays, reducing power, and FRAP). Ethanolic extracts presented a significantly higher antioxidant activity $(p<0.05)$ except for FRAP, in which the best results were achieved by the aqueous extracts. Methanolic extracts showed the lowest radical scavenging activities for both DPPH· and NO· radicals.
\end{abstract}

Keywords: Cymbopogon citratus, Phytochemical screening, Nutritional value, Bioactive compounds, Antioxidant activity assays

\section{Introduction}

Since ancient times, the medicinal properties of plants have been investigated due to their powerful pharmacological proper- ties. Over the centuries, people have been living in close associa- tion with the environment and relying on its flora and fauna as a source of food and medicine (Moshi et al., 2012; Cheikhyoussef et al., 2011; Gurib-Fakim, 2006). Crude plant extracts (e.g. infusion, tincture, decoction or others) are traditionally used by populations all over the world for medicinal purposes. Although their effective- ness and mechanisms of action have not been scientifically tested in the majority of the cases, they often mediate beneficial responses due to their bioactive chemical components (Barnes et al., 2007). The organic compounds usually related with physio- logical actions on the human body include alkaloids, phenolics, flavonoids, tannins, terpenoids, andsteroids (Yadavand Agarwala, 2011).

Popular African culture include powerful indigenous therapies that can surpass medicines from industrialized countries. All over the world, Republic of Angola is recognized for its remarkable plants biodiversity, which can be explored in a rational way for humankind benefits. Several species from the Angolan flora, tradi- tionally selected for medicinal uses, have been the target of currentinvestigations searching for therapeutically effective drugs with antioxidant, antimicrobial, and antifungal properties (Nema et al., 2012; Kennedy and Wightrman, 2011; Silva et al., 2011; Lulekal et al., 2008; Atawodi, 2005).

Cymbopogon citratus (Poaceae family) is an Angolan medicinal plant widely used by local people for treating high fever, stomach, gut problems and headache. Due to the pleasant aroma of its 
infusion, this plant is widely known and used in tropical and sub- tropical countries. It can also act as an antidepressant and as a mood enhancer. Other researches also reported hypoglycemic, hypolipidemic, anxiolytic, sedative (Blanco et al., 2009) and antiox-idant properties (Pereira et al., 2009; Figueirinha et al., 2008; Cheel et al., 2005; Cheah et al. 2001).

C. citratus has shown potential as a source of chemotherapeutic compounds. Figueirinha et al. (2008) reported that $C$. citratus leaves exhibit antiradical capacity against the 2,2-diphenyl-1-pic- rylhydrazyl radical $\left(\mathrm{DPPH}^{-}\right)$and identified tannins, phenolic acids (caffeic and $p$ coumaric acid derivatives) and flavone glycosides (apigenin and luteolin derivatives). In another study, isoorientin, isoscoparin, swertiajaponin, isoorientin $2^{00}$-O-rhamnoside, orientin, chlorogenic acid, and caffeic acid were isolated from C. citratus ex- tracts (Cheel et al., 2005).

This aromatic plant has also been reported by its antimicrobial activity against Aspergillus species, Escherichia coli, Pseudomonas aeruginosa, Streptococcus pneumonia and S. pyogenes, (Matasyohet al., 2011; Aboaba et al., 2006).

Although there are few studies in literature regarding proximal composition of Nigerian C. citratus leaves and respective extracts (Asaolu et al. 2009; Oloyede, 2009; Akande et al., 2012), as far as we know, there are no studies so far concerning the nutritional va- lue of the Angolan C. citratus. Knowing that the geographical origin and edaphoclimatic conditions may significantly affect plants com- position, the aim of this study was to characterize the nutritional composition of the leaves of this plant in order to evaluate eventual differences from those previously described in literature. The con- tents of bioactive phytochemicals and the total antioxidant activity of different extracts of the Angolan C. citratus were also studied in order to predict potential industrial applications (food, supplemen- tation or cosmetic fields) of this plant.

\section{Material and methods}

\subsection{Reagents and standards}

Hydrochloric acid, Sodium nitrate, ferric chloride, aluminum chloride, TPTZ solution, catechin, 2,6-dichlorophenol (Tillmans reagent), sodium carbonate, oxalic acid, ethanol, petroleum ether, ascorbic acid and 2,2-diphenyl-1-picrylhydrazyl radical (DPPH') were obtained from Sigma-Aldrich (St. Louis, MO, USA). Methanol, the Folin-Ciocalteu reagent, sodium hydroxide, and gallic acid were purchased from Panreac Química S.L.U. (Barcelona, Spain). Anhydrous sodium carbonate, sodium hydroxide and ethanol were obtained from Merck (Darmstadt, Germany). All chem- icals and reagents used were of analytical grade and used without further purifica-

tion. All aqueous solutions were prepared with Milli $Q$ filtered water (resistivity > $18 \mathrm{MX} \mathrm{cm}$ ) (Millipore, Bedford, MA).

\subsection{Samples}

Cymbopogon citratus leaves were collected in Benguela, a city located in Western Angola (coordinates: $12033^{\circ}$ S, $130 \quad 25^{\circ}$ E). Plants were identified in the Polytechnic Superior Institute of Benguela, Angola. The leaves were picked and washed with water to remove all unwanted materials, dried in the dark $(250 \mathrm{OC} \pm 2$ $0 C$ ) and stored in an airtight container for further use before being ground to fine powder.

\subsection{Nutritional composition}

The C. citratus dried leaves were analyzed for nutritional composition using AOAC procedures (1995). For moisture, powdered leaves $(1 \mathrm{~g})$ were placed within a porcelain capsule in a stove (WTC binder Klasse 2.0, Tuttlingen, Germany) at $1050 \mathrm{OC} \pm 10 \mathrm{C}$, until constant weight was achieved. The ash content was determined by incineration at $600 \pm 100 \mathrm{C}$. The crude protein content was estimated by the Kje-

ฮ̊
0
$\frac{0}{ \pm}$
$\frac{0}{0}$
$\frac{0}{0}$
$\frac{0}{0}$ 


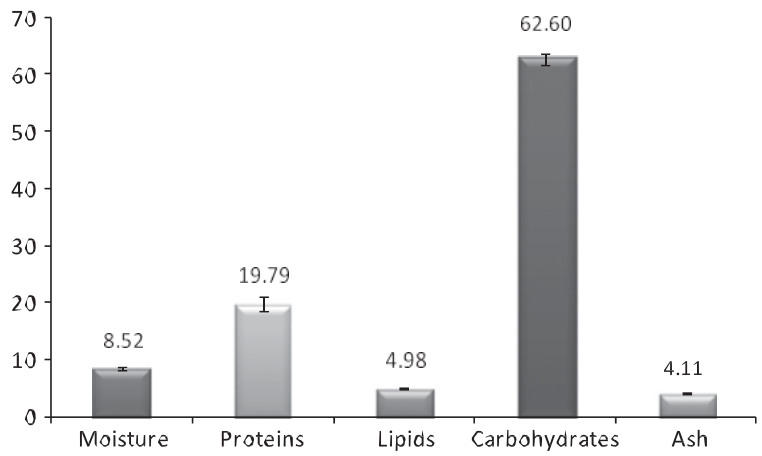

Fig. 1. Nutritional composition of Angolan Cymbopogon citratus leaves.

\subsection{Phytochemical screening}

A small portion of dried powdered leaves was used for the phytochemical screening tests in order to detect the presence of tannins, flavonoids, steroids, alka- loids, and terpenoids, according to different methods previously described with some modifications (Vinha et al., 2012; Harborne, 1998; Sofowara, 1993; Trease and Evans, 1989).

Briefly, $1.0 \mathrm{~g}$ of sample was mixed with $10 \mathrm{ml}$ of three different solvents (dis- tilled water, ethanol and methanol) to obtain three different extracts, which were subsequently filtered (using Whatman No. 1 filter paper).

A blue coloration resulting from the addition of ferric chloride reagent indicated the presence of tannins in the extract.

About $2 \mathrm{ml}$ of the extracts were mixed with $2 \mathrm{ml}$ of methanol and heated, fol- lowed by the addition of a few drops of concentrated $\mathrm{HCl}$. The occurrence of a red or orange coloration was indicative of flavonoids presence.

For alkaloids screening, $2 \mathrm{ml}$ of the plant extracts were added into $5 \mathrm{ml}$ of $1 \% \mathrm{HCl}$ on a steam bath and $1 \mathrm{ml}$ of the final filtrate was treated with few drops of Dragendorff's reagent. Turbidity or precipitation was

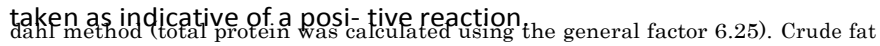
was determined by extracting a known aliquot of sample (ffil $\mathrm{g}$ ) with petroleum ether, using a Soxhlet apparatus. Total carbohydrates were calculated by difference. Results for each parameter were expressed in percentage (\%). The
energy value of

the leaves was determined by using the Atwater factors. Results are reported in Fig. 1.
About $1 \mathrm{ml}$ of each extract was mixed with $3 \mathrm{ml}$ of acetic anhydride. Concen- trated $\mathrm{H} 2 \mathrm{SO} 4$ was carefully added to the filtrate to promote the phase's separation. Blue or green color formation indicated the presence of steroids. For the detection of terpenoids (Salkowski test), $3 \mathrm{ml}$ of sample extracts were mixed in $2 \mathrm{ml}$ of chloroform and $3 \mathrm{ml}$ of concentrated $\mathrm{H} 2 \mathrm{SO} 4$. A red-dish brown color at the interface was taken as positive for terperoid.

Results are reported in Table 1.

\subsection{Bioactive phytochemicals determination}

\subsubsection{Plant extracts preparation}

A $5 \mathrm{~g}$ of powdered sample were added into $50 \mathrm{ml}$ of three different solvents (distilled water, ethanol, and methanol) and allowed to stand at $40 \mathrm{OC}$, under con- stant agitation during $1 \mathrm{~h}$. The resultant extracts were then filtered (using double filter paper) for further experiences. Dilutions were performed if necessary.

\subsubsection{Total phenolics}

Total phenolics were determined colorimetrically according to Vinha et al. (2012). Briefly, 200 II of each extract was mixed with 1.5 $\mathrm{ml}$ of Folin-Ciocalteau re- agent (1:10), and allowed to stand at 22 $0 \mathrm{C} \pm 10 \mathrm{C}$, for $5 \mathrm{~min}$. A $1.5 \mathrm{ml}$ of sodium

bicarbonate solution (8\%) was added to the mixture. After $60 \mathrm{~min}$ at 22 OC \pm 1 OC, absorbance was measured at $725 \mathrm{~nm}$ using a UV-Vis spectrophotometer (Shima- dzu, model UV-1800). Total phenolic contents were quantified through a calibration curve obtained from measuring the absorbance of known concentrations of a gallic acid standard $(r=0.9992)$. The results were expressed as $\mathrm{mg}$ of gallic acid equiva- lents (GAE)/ml of extract (Table 2 ).

\subsubsection{Total flavonoids}

Total flavonoids were measured using the aluminum chloride assay, previously described by Zhishen et al. (1999). Distilled water (4 $\mathrm{ml}$ ) and 5\% Na2NO3 (300 II) were added to an aliquot $(1 \mathrm{ml})$ of extract and to the catechin standard solutions

\section{Table 1}

Phytochemical constituents of leaves extracts of Cymbopogon citratus. ${ }^{a}$

\begin{tabular}{lllllll} 
Plant extracts & Tannins & Flavonoids & Alkaloids & Steroids & Terpeno \\
\hline & & & & & & \\
Aqueous & + & + & & & & + \\
Ethanolic & + & + & & & & + \\
Methanolic & + & + & + & + & + \\
\hline
\end{tabular}

a (+) Presence of phytochemical compounds. ( ) Absence of phytochemical compounds. 
Table 2

Bioactive compounds analysis of the aqueous, ethanolic and methanolic extracts of Angolan C. citratus leaves.

Bioactive compounds Cymbopogon citratus extracts

\begin{tabular}{llll}
\cline { 2 - 4 } & Aqueous & Ethanolic & Methanolic \\
\hline Phenolics (mg & $4.28 \pm$ & $6.11 \pm 0.11^{\mathrm{a}}$ & $3.26 \pm 0.26^{\mathrm{c}}$ \\
$\mathrm{GAE} / \mathrm{ml})$ Flavonoids & $0.24^{\mathrm{b}}$ & $6.62 \pm 0.65^{\mathrm{a}}$ & $3.47 \pm 0.49^{\mathrm{c}}$ \\
$(\mathrm{mg} \mathrm{CE} / \mathrm{ml})$ Tannins & $5.04 \pm$ & $1.88 \pm$ & $2.32+0.16^{\mathrm{a}}$ \\
\hline
\end{tabular}

*Values expressed as mean \pm standard deviation obtained from 3 measurements. For each group of compounds (within each table line), different letters ( $a, b$ or $c$ ) represent significant differences at $p$ $<0.05$. The same letter indicates that there are no significant differences $(p>0.05)$ between results.

( $r=0.9987)$. A volume of $300 \mathrm{II}$ of $10 \% \mathrm{AlCl} 3$ was added after $5 \mathrm{~min}$ at quiescent, fol- lowed by $2 \mathrm{ml}$ of $\mathrm{NaOH}(1 \mathrm{M})$ after another minute. The total volume was fulfilled till $10 \mathrm{ml}$. The resultant solution was homogenized and absorbance measured at $510 \mathrm{~nm}$ against a reagent blank. Total flavonoid content was expressed as mg cat- echin equivalents $(C E) / \mathrm{ml}$ of extract (Table 2 ).

\subsubsection{Tannins}

The content of tannins was determined according to a previously described pro- cedure (Schneider, 1976). $2 \mathrm{ml}$ of plant extract were mixed with $8 \mathrm{ml}$ of water and $10 \mathrm{ml}$ of acetate buffer (solution 1, S1). An aliquot of this solution $(10 \mathrm{ml})$ was sub- sequently shaken with 50 mg of casein during 60 min and, after that, filtered (solu-tion 2, S2). 1 $\mathrm{ml}$ of each previously prepared solution $(\mathrm{S} 1, \mathrm{~S} 2)$ was mixed separately with 500 II of Folin-Denis reagent and, then, both solutions were diluted to $10 \mathrm{ml}$

with sodium carbonate decahydrate solution (33\%). The absorbance of such pre- pared solutions was measured against a blank sample at $720 \mathrm{~nm}$. The tannins con- tent was evaluated upon three independent analyses. Absorbance values obtained for S1 corresponded to total polyphenol content. Differences between absorbance of solutions S1 and S2 correspond to content of casein-adsorbed tannins in C. citratus extracts $(r=0.9945)$. The contents of tannins were expressed as $\mathrm{mg}$ of catequin equivalents (CE)/ml of extract (Table 2 ).

\subsubsection{Ascorbic acid content}

Ascorbic acid content was determined according to the modified 2,6-dichloro- phenolindophenol (DIP) method (Franck et al., 2003). $20 \mathrm{ml}$ of oxalic acid (0.4\%) were added to each sample extract (5 $\mathrm{ml}$ ) and mixed for $1 \mathrm{~h}$. The final solution was filtered and $5 \mathrm{ml}$ were added to $10 \mathrm{ml}$ of oxalic acid and $1 \mathrm{ml}$ of $\mathrm{HCl}(1 \mathrm{M})$. Quantification was obtained from a standard curve $(r=0.9993)$ of ascorbic acid (AA) per $\mathrm{ml}$ of extract (Table 2).

\subsection{Antioxidant activity}

\subsubsection{Reducing power assay}

The reducing power of each extract was evaluated according to the method of Chou et al. (2009). Extracts (250 II) were mixed with 250 II of sodium phosphate buffer $(0.2 \mathrm{M}, \mathrm{pH} \mathrm{6.6)}$ and 250 II of potassium ferric cyanide $(1 \%, \mathrm{w} / \mathrm{v})$. The resulting mixture was incubated at $50 \mathrm{OC}$ for $20 \mathrm{~min}$. After, 250 II of trichloroacetic acid (10\%) were added to the mixture to stop the reaction, followed by centrifugation at control solution was pre- pared in the same conditions but without plant extracts. The absorbance was mea- sured at $700 \mathrm{~nm}$ in a microplate reader (Synergy ${ }^{\circledR}$ HT BioTek.). The reducing power of the plant extract shows a linear correlation with the concentration of the sample. Final results were expressed as $\mathrm{mg}$ of ascorbic acid equivalents $(A A E) / m l$ of extract (Fig. 2).

\subsubsection{Scavenging of diphenyl-picrylhydrazyl (DPPH·) radical}

The scavenging activity of the extracts was determined based on DPPH' scav- enging assay described by Molan et al. (2009). Briefly, 25 II of each plant extract was allowed to react with 250 II of $0.2 \mathrm{mM}$ $\mathrm{DPPH}^{\cdot}$ in $95 \%$ ethanol in a 96-well

microplate. The absorbance was measured at $550 \mathrm{~nm}$ using a microplate reader plate (after incubation in dark at room temperature for $30 \mathrm{~min})$. All determinations were performed in triplicate in two separate experiments. Ascorbic acid was used as standard and final results were expressed in terms of ascorbic acid equivalents (AAE)/ml of extract (Fig. 2).

\subsubsection{Ferric reducing antioxidant power assay (FRAP)}

The capacity to reduce ferric ions was determined using the Ferric Reducing Antioxidant Power (FRAP) assay as described by Benzie and Strain (1996), with slight modifications (Molan et al., 2009). Briefly, an aliquot of 8.5 II of each plant extract was added to 275 II of diluted FRAP reagent (1:1 with water) directly in 
a microplate. The plates were incubated at $370 \mathrm{C}$ during $15 \mathrm{~min}$ and the absorbance was read at $595 \mathrm{~nm}$. Final results were expressed as ascorbic acid equivalents (AAE)/ml of extract (Fig. 2).

\subsubsection{Nitric oxide (NO) radical scavenging assay}

Nitric oxide radical scavenging method was determined based in preview works (Badami et al., 2005; Govindarajan et al., 2003). 2.0 $\mathrm{ml}$ of sodium nitroprusside

( $\mathrm{Na2}[\mathrm{Fe}(\mathrm{CN}) 5 \mathrm{NO}]-2 \mathrm{H} 2 \mathrm{O})$ in phosphate buffer $(10 \mathrm{mM})$ were added to 500 II of each

plant extract. The final solution was then incubated at $250 \mathrm{OC}$ (water bath) during $60 \mathrm{~min}$, and after incubation, $2.5 \mathrm{ml}$ of Griess reagent (1\% sulphanilamide, $0.1 \%$ naphthyethylene and diamine dihydrochloride in $2 \% \mathrm{H}_{3} \mathrm{PO} 3$ ) were added. Absor- bance of the chromophore formed was registered at $540 \mathrm{~nm}$. NO- radical scavenging

activity was expressed in terms of ascorbic acid equivalents ( $\mathrm{mg}$ $\mathrm{AAE}) / \mathrm{ml}$ of extract (Fig. 2).

\subsubsection{Hydrogen peroxide ( $\mathrm{H}_{2} \mathrm{O} 2$ ) scavenging assay}

The ability of $C$. citratus extracts to scavenge hydrogen peroxide was deter- mined according to Ruch et al. (1989). A hydrogen peroxide solution $(40 \mathrm{mM})$ was prepared in phosphate buffer $(50 \mathrm{mM}, \mathrm{pH} \mathrm{7.4)}$ and $2 \mathrm{ml}$ of the final solution was added to $1 \mathrm{ml}$ of plant extracts (1:20 dilution). The absorbance was measured after $10 \mathrm{~min}$ of incubation at $230 \mathrm{~nm}$, against a blank solution. $\mathrm{H}_{2} \mathrm{O} 2$ radical scav- enging activity was expressed in terms of ascorbic acid equivalents (mg AAE)/ml of extract (Fig. 2).

\subsection{Statistical analysis}

Data are reported as mean \pm standard deviation of three independent measure- ments. Statistical analyses were performed using the statistical package SPSS v15.0 (SPSS for Windows; SPSS Inc., Chicago, IL). One-way ANOVA was used to compare groups, and post hoc Dunnett's test was performed for simultaneous paired comparisons. Simple linear regression analysis was used to evaluate correlations be- tween different parameters.

\section{Results and discussion}

Medicinal plants are of great importance for both individual and community health. It is well known that medicinal and aromatic plants production is challenging and involves a wide variety of is- sues, including agricultural, commercial, ecological, pharmacologi- cal, as well as social (Vinha et al., 2012). Angola is acknowledged for its botanical richness, by resorting to natural therapies, and also by its limited information about their endemic plants (Schoeman et al., 2013).

C. citratus species, currently known as lemon grass, besides the medicinal use, may be also used in the food industry (for preserva-tive and aromatic purposes), as well as in cosmetics and pharma-ceutical industries (Mirghani et al., 2012; Sessou et al., 2012). Recently, there has been a considerable interest in extracts from aromatic plants with antioxidant activities for potential industrial applications. In this work, we tried to demonstrate the high poten- tial of the endemic Angolan $C$. citratus leaves.

\subsection{Nutritional characterization}

The proximate composition of the leaves of $C$. citratus is shown in Fig. 1. On average, the increasing order of the analyzed nutrients was: ash $<$ fat $<$ moisture < protein < carbohydrates. The moisture and ash contents of the leaves were $8.52 \%$ and $4.11 \%$, respectively. Crude protein and fat levels were $19.79 \%$ and $4.98 \%$, correspond- ingly, and total carbohydrate represented about $60 \%$ of $C$. citratus leaves. The calculated energetic value of $C$. citratus leaves corre-sponded to $374 \mathrm{kcal} / 100 \mathrm{~g}$.

These results are slightly different than those described by Oloyede
(2009) for Nigerian C. citratus leaves which contained a lower lipid amount (rv1\%). Comparatively, the Angolan leaves ana-lyzed in this study are a better source of the so appreciated lemongrass essential oil. Oloyede (2009) also reported a higher ash amount (rv13\%). The higher mineral content reported by Oloyede(2009) is mainly to due to high P contents that can be related tothe soil type or cropping practices. Referring to the total carbohy-drate, our values are in accordance with those described by 


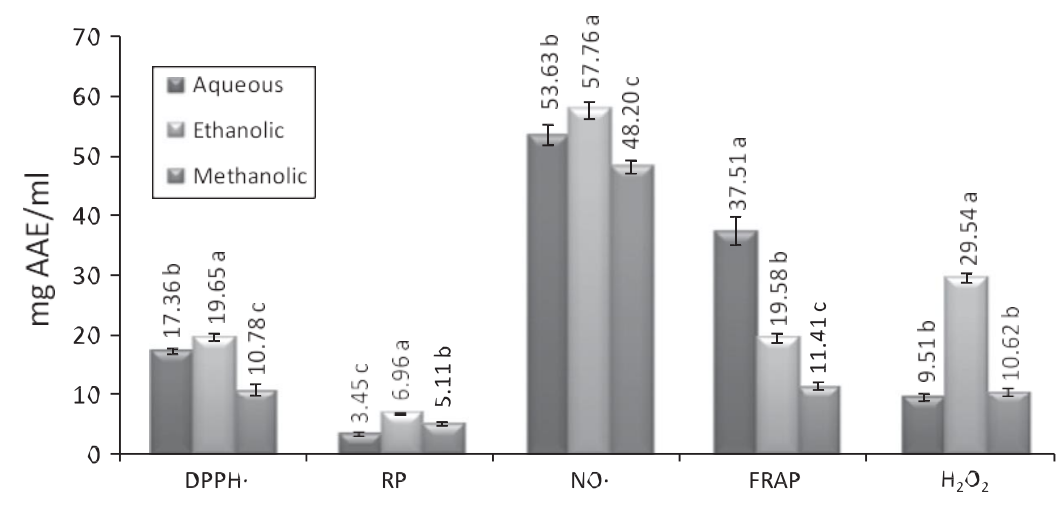

Fig. 2. Total antioxidant capacity of aqueous, ethanolic, and methanolic extracts obtained by $C$. citratus leaves. Legend: AAE, ascorbic acid equivalents; DPPH', diphenyl- picrylhydrazyl radical scavenging assay; RP, reducing power assay; NO; nitric oxide radical scavenging assay; FRAP, ferric reducing antioxidant power assay; $\mathrm{H} 2 \mathrm{O} 2$, Hydrogen peroxide scavenging assay. For each assay, different letters indicate statistical significant differences $(p<0.05)$ caused by the solvent extraction.

Oloyede (2009). Although fiber content was not analyzed in this study, high fiber content in leaves (Oloyede, 2009) and leaf extracts(Asaolu et al., 2009) are described in literature (rv28\% and 55\%, respectively), showing that this plant could be an interesting source of fiber for a potential application in food and food supple- ments industries.

\subsection{Phytochemical screening}

Preliminary screening tests are useful in the detection of bioac- tive principles and subsequently may lead to drugs discovery and development. In the present study, several phytochemical constit-uents were evaluated qualitative and quantitatively.

Table 1 shows the results obtained for the phytochemical screening analysis conducted on $C$. citratus extracts. The presence of tannins, flavonoids and terpenoids was observed in all the 3 ex- tracts analyzed, while alkaloids and steroids were absent in aque- ous and ethanolic extracts.

Extraction is a fundamental step in the medicinal plants analy- sis, since it is essential to obtain and purify the desired chemical constituents from the plant material for further characterization. Extraction with different solvents is frequently used for isolation and quantification of antioxidant compounds, and both extraction yield and antioxidant activity of the extracts are strongly corre- lated with the solvent employed. This is mainly due to the differentpolarity of those compounds, once each matrix-solvent system shows a particular behavior that cannot be predicted (Al-Farsi and Lee, 2008). For this reason, in this work, different solvents were assayed for the extraction of $C$. citratus leaves (water, ethanol and methanol).

Our results support that the edaphic and climatic conditions may promote differences in the synthesis of secondary metabolites which may contribute to the medicinal value as well as physiolog-ical activity of the plant part evaluated (Edoga et al., 2005). Indeed, an Indian study reported that both methanolic and aqueous $C$. cit- ratus extracts contained no alkaloids or steroids (Dama et al., 2011). On the other hand, we obtained a similar profile to $C$. citra- tus leaf extracts studied in Nigeria (Asaolu et al., 2009; Danlami et al., 2011; Ewansiha et al., 2012).

Considering the variability of the extracted chemical compound classes described in Table 1, methanol seems to be the best extrac- tor solvent; however, regarding its toxicity and a potential domes- tic therapeutic application, the extracts obtained with water and ethanol seem to be quite satisfactory alternatives. Moreover, depending on the type and amount of alkaloids present in the methanolic extract, this could present some kind of toxicity that should be characterized and monitored, if necessary.

\subsection{Bioactive compounds}

Most of the polyphenolic compounds in nature have antioxi- dant activities. Water and alcohol were primarily selected as the extraction solvents since both are more innocuous (in comparison with other solvents) and commonly used in the food industry. Nev- ertheless, methanol was also used as extractor solvent in this work, since previous studies reported better extraction rates for several bioactive compounds in this type of extracts (Bae et al., 2012; Cau- nii et al., 2012; Akowuah et al., 2002).

As shown in Table 2, flavonoids were the major components of C. citratus extracts, while tannins represented, generally, the minorgroup. Phenols and polyphenols are secondary metabolites foundin high amount in plants. The lowest contents of tannins may bedue to the fact that these compounds belong to the flavonoidsgroup which basic chemical structure is $\mathrm{C}_{6}-\mathrm{C}_{3}-\mathrm{C}_{6}$. So, our results indicated the presence of polymeric tannins, which in small amounts do not have toxicity.

Significant differences $(p<0.05)$ were observed between the to- tal phenolic and flavonoid contents among the different plant ex-tracts. The ethanolic extract was found to have the highest total phenolic and flavonoid amounts, while methanolic one presentedthe lowest contents ( $p$ $<0.05$ ) of both groups of compounds. Onthe other hand, this last extract contained significantly higher lev-els $(p<0.05)$ of tannins. The highest content of ascorbic acid wasfound in the aqueous extract, as expected, due to the high hydro-solubility of the molecule.

\subsection{Antioxidant activities}

Natural antioxidants are considered to be multifunctional and of high interest as alternatives to synthetic antioxidants to reduce oxidation in complex food systems. Their activity depends on sev- eral parameters such as the multiplicity and heterogeneity of the plant matrix, edaphic and climatic conditions of the production re- gion and the experimental conditions used for the product achieve- ment (Vinha et al., 2012). It is well known that the antioxidant properties of plant extracts cannot be evaluated by one single method due to the complex nature of phytochemicals. Instead, thorough antioxidant assays should involve several activity stud-ies, with dissimilar and complementary mechanisms of action (Gioti et al.,2009).

In this work, five methods were used to evaluate total antioxi- dant capacity of the different extracts (DPPH', $\mathrm{NO}^{\circ}$, and $\mathrm{H}_{2} \mathrm{O}_{2}$ scav- enging assays, reducing power method, and FRAP). Results are depicted in Fig. 2. 
In general, significant differences $(p<0.05)$ were observed among the antioxidant activities of the three extracts evaluated. The ethanolic extract presented a superior total antioxidant capacity, with significantly higher results $(p<0.05)$ for all assays, except for the FRAP method, in which the aqueous extract showed the best results. The FRAP mechanism is based in an elec- tron transfer, being very useful to distinguish dominant mecha- nisms of antioxidant action, in combination with the other methods (Ronald et al., 2005). On the other hand, the aqueous ex- tract showed the lowest reducing power. The methanolic extract, although often referred as the best solvent to extract antioxidant compounds from vegetable matrixes, presented in this study the lowest radical scavenging activities against both $\mathrm{DPPH}^{\cdot}$ and NO radicals.

Our results are slightly different from those reported by Pereira et al.

(2009) that found similar DPPH' inhibition for methanolic and ethanolic extracts of $C$. citratus and lower scavenging activity for aqueous extracts. These differences should be mainly due to the different procedures used to prepare sample extracts, since Pereira et al. (2009) macerated the sample in the dark for 7 days with methanolor ethanol and prepared the aqueous extracts by infusion just before use. On the other hand,

Figueirinha et al. (2008) found higher DPPH' inhibition for infusion, followed by $80 \%$ aqueous eth- anol, decoction, and methanol extracts, by this order. In another study, Tapia et al. (2007) identified the most active

DPPH' scaven- ger compounds from $C$. citratus cultivated in bioreactors by the temporary immersion principle as caffeic acid, chlorogenic acid, neochlorogenic acid, and the flavonoid luteolin 6-C-fucopyranoside.

Hydrogen peroxide when converted into hydroxyl radicals $(\cdot \mathrm{OH})$ can present toxicity to living cells, by reacting with biomol- ecules, and cause tissue damage and cell death (Khan et al., 2012). No significant differences $(p>0.05)$ were observed between $\mathrm{H}_{2} \mathrm{O}_{2}$ scavenging activity of aqueous and methanolic extracts. In this case, ethanol extraction achieved better results.

\subsection{Correlations}

According to the previously discussed results, distinct solvents produced C. citratus extracts with significantly different antioxi- dant activities. Concordantly, the extracts composition regarding bioactive phytochemicals content also differed between samples. It was possible to observe some high correlations between the ana- lyzed parameters, which

are detailed in Table 3. The DPPH' results showed a positive correlation with total phenolics $(r=0.8944)$, and flavonoids $(r=0.9178)$. In addition, NOscavenging activity was also significantly correlated to flavonoids $(r=$ 0.9263 ) and total phenolics $(r=0.9051)$. Obviously, a high correlation coefficient was observed between results of these both antioxidant activity assays $(r=0.9618)$. On the other hand, the levels of tannins were inversely correlated with values obtained in FRAP assay $(r=$ 0.8046), while total phenolics and flavonoids showed very low correlation coefficients. This behavior was probably due to dif- ferent mechanisms of antioxidant action of the analyzed phytochemicals.

A validation of the antioxidant capacity approach is crucial for investigating the role, in human health, of natural antioxidants present in foods. This work intended to approve that the content of different secondary metabolites of $C$. citratus and other plant matrices are dependent upon the solvent used to extract them, an effect that is most likely due to the different phytochemical pro- files of the respective extracts. Our results are in agreement with Xu and Chang (2007) who reported that total phenols and flavo- noids contents in soybeans and their effects on the FRAP, ORAC, and DPPH assays may vary with the extraction solvent choice.
Table 3

Correlation coefficients between the different parameters

\begin{tabular}{|c|c|c|c|c|c|}
\hline \multicolumn{2}{|c|}{$\begin{array}{l}\text { andyzed. Parameters } \\
\text { DPPH Phenolics }\end{array}$} & \multirow{2}{*}{$\begin{array}{l}0.8944 \\
0.9178\end{array}$} & \multicolumn{2}{|c|}{ Paramteters } & \multirow[b]{2}{*}{0.2670} \\
\hline DPPH & Flavonoids & & DPPH & $\mathrm{RP}$ & \\
\hline DPPH & Tannins & 0.5914 & DPPH & NO & 0.9618 \\
\hline DPPH & Ascorbic acid & 0.1349 & DPPH & FRAP & 0.5348 \\
\hline $\mathrm{RP}$ & Phenolics & 0.6422 & DPPH & $\mathrm{H}_{2} \mathrm{O}_{2}$ & 0.6585 \\
\hline $\mathrm{KP}$ & F'lavonoids & 0.5062 & $\mathrm{RP}$ & NO & 0.4246 \\
\hline $\mathrm{RP}$ & Tannins & 0.2581 & $\mathrm{RP}$ & FRAP & 0.6267 \\
\hline $\mathrm{RP}$ & Ascorbic acid & 0.7744 & $\mathrm{RP}$ & $\mathrm{H}_{2} \mathrm{O}_{2}$ & 0.8903 \\
\hline NO & Phenolics & 0.9051 & NO & FRAP & 0.3407 \\
\hline NO & Flavonoids & 0.9263 & NO & $\mathrm{H}_{2} \mathrm{O}_{2}$ & 0.7639 \\
\hline NO & Tannins & 0.3817 & FRAP & $\mathrm{H}_{2} \mathrm{O}_{2}$ & 0.2623 \\
\hline
\end{tabular}

\begin{tabular}{llrlll} 
NO. & Ascorbic acid & 0.3345 & & & \\
FRAP & Phenolics & 0.1517 & & & \\
FRAP & Flavonoids & 0.2982 & Phenolics & Flavonoids & 0.9389 \\
FRAP & Tannins & & Phenolics & Tannins & 0.3863 \\
FRAP & Ascorbic & 0.6284 & Phenolics & Ascorbic acid & 0.4191 \\
$\mathrm{H} 2 \mathrm{O} 2$ & Phenolics & 0.9061 & Flavonoids & Tannins & 0.4401 \\
$\mathrm{H} 2 \mathrm{O} 2$ & Flavonoids & 0.7959 & Flavonoids & Ascorbic acid & 0.3659 \\
$\mathrm{H} 2 \mathrm{O} 2$ & Tannins & & Tannins & Ascorbic acid & 0.4720 \\
$\mathrm{H} 2 \mathrm{O} 2$ & Ascorbic & $n n 1$ & & & \\
& acid & 0.7065 & & & \\
\hline
\end{tabular}

${ }^{a} \mathrm{DPPH}^{\cdot}$, scavenging of diphenyl-picrylhydrazyl radical; RP, reducing power assay; NO', nitric oxide radical scavenging assay; FRAP, ferric reducing antioxidant power assay; $\mathrm{H} 2 \mathrm{O} 2$, hydrogen peroxide scavenging assay.

\section{Conclusion}

Plant phytochemicals are used due to their medicinal and phys- iological properties. Further work should be carried out to isolate, purify, and characterize the active constituents responsible for the activity of these plants.

The Angolan C. citratus leaves analyzed in this study were mainly constituted by carbohydrates, followed by protein, fat, ash and moisture. Tannins, flavonoids, and terpenoids were detected in all the extracts prepared, though methanolic ones also revealed the presence of alkaloids and steroids.

Ethanolic extracts contained higher amounts of total phenolics and flavonoids while tannins content was higher in methanolic extracts. Aqueous extracts presented higher levels of ascorbic acid. A significantly higher antioxidant activity $(p<0.05)$ was found inethanolic extracts for all assays, except for the FRAP method, in which the aqueous extract showed the best results. The aqueous extract showed the lowest reducing power and the methanolic ones presented the lowest radical scavenging activities for bothDPPH' and NO radicals.

In general, significant differences $(p<0.05)$ were observed between the antioxidant activities of the three types of extracts studied. The differences found between assays result not only from the chemical composition of the extracts (which vary with the extracting solvent) but also from the different antioxidant mecha- nisms tested in each assay.

Conflict of Interest

The authors declare that there are no conflicts of interest. 
Rita C. Alves is grateful to FCT for a post-doctoral research grant (SFRH/BPD/68883/2010) financed by POPH -QREN -Tipologia 4.1 Formação Avançada, subsidized by Fundo Social Europeu and Min-istério da Ciência, Tecnologia e Ensino Superior. This work has beensupported by FCT through grant no. PEst-C/EQB/LA0006/2011. 


\section{References}

Aboaba, O.O., Smith, S.I., Olide, F.O., 2006. Antimicrobial effect of edible plant extract on Escherichia coli 0157:H7. Pak. J. Nutr. 5, 325-329.

Al-Farsi, M., Lee, C.Y., 2008. Optimization of phenolics and dietary fibre extraction

from date seeds. Food Chem. 108, 977-985.

Akande, I.S., Samuel, T.A., Agbazue, U., Olowolagbab, L., 2012. Comparative proximate analysis of ethanolic and water extracts of Cymbopogon citratus (lemon grass) and four tea brands. JPBMS 22, 3.

Akowuah, G.A., Sadikun, A., Mariam, A., 2002. Flavonoid identification and hypoglycemic studies of butanol fraction from Gynura procumbens. Pharm. Biol. 40, 405-410.

AOAC, 1995. Official Methods of Analysis, 16th ed. Association of Official Analytical Chemists, Arlington VA, USA.

Asaolu, M.F., Oyeyemi, O.A., Olanlokun, J.O., 2009. Chemical composition, phytochemical constituents and in vitro biological activity of various extracts of Cymbopogon citratus. Pak. J. Nutr. 8, 1920-1922.

Atawodi, S.E., 2005. Antioxidant potential of African medicinal plants. Afr.' J.

Biotechnol. 4, 128-133.

Badami, S., Rai, R.S., Suresh, B., 2005. Antioxidant activity of Aporosa

lindleyana root.

J. Ethnolpharmacol. 37 (35), 1-5.

Bae, H., Jayaprakasha, G.K., Crosby, K., Jifon, J.L., Patil, B.S., 2012. Influence of extraction solvents on antioxidant activity and the content of bioactive compounds in non-pungent peppers. Plant Foods Hum. Nutr. 67, 120-128.

Barnes, J., Anderson, L.A., Phillipson, J.D., 2007. Herbal Medicines, third ed.

Pharmaceutical Press, London.

Benzie, I.F.F., Strain, J.J., 1996. The ferric reducing ability of plasma (FRAP) as a measure of "antioxidant power": the FRAP assay. Anal. Biochem. 239, 70-76.

Blanco, M.M., Costa, C., Freire, A.O., Santos Jr., J.G., Costa, M., 2009. Neurobehavioral effect of essential oil of Cymbopogon citratus in mice. Phytomedicine 16, 265- 270.

Caunii, A., Pribac, G., Grozea, I., Gaitin, D., Samfira, I., 2012. Design of optimal solvent for extraction of bio-active ingredients from six varieties of Medicago sativa. Chem. Central J. 6, 1-8.

Cheah, P.B., Ng, C.H., Wong, C.F., 2001. Antioxidant activity of tropical lemon grass (Cymbopogon citratus) extracts in linoleic acid and chicken fat systems. J. Food Sci. Technol. 38, 62-64.

Cheel, J., Theoduloz, C., Rodriguez, J., Schmeda-Hirschmann, G., 2005. Free radical scavengers and antioxidants from lemongrass (Cymbopogon citratus (DC.) Stapf.). J. Agric. Food Chem. 53, 25112517.

Cheikhyoussef, A., Mapaure, I., Shapi, M., 2011. The use of some indigenous plants for medicinal and other purposes by local communities in Namibia with emphasis on Oshikoto region: a review. Res. J. Med. Plants. 5, 406-419.

Chou, H.J., Kuo, J.T., Lin, E.S., 2009. Comparative antioxidant properties of water extracts from different parts of beefsteak plant (Perilla frutescens). J. Food Drug Anal. 17, 489-496.

Dama, G.Y., Tare, H.L., Gore, M.S., Deore, S.R., Bidkar, J.S., 2011. Comparative hemintholytic potential of extracts obtained from Cymbopogon citratus and Wrightia tinctoria leaves. Int. J. Pharma Bio Sci. 2, 321-327.

Danlami, U., Rebecca, A., Machan, D.B., Sunday, Asuquo, T.S., 2011. Comparative study on the antimicrobial activities of the ethanolic extracts of lemon grass and Polyalthia Longifolia. J. Appl. Pharm. Sci. $1, \quad 174-176$.

Edoga, H.O., Okwu, D.E., Mbaebie, B.O., 2005. Phytochemicals constituents of some

Nigerian medicinal plants. Afr. J. Biotechnol. 4, 685-688.

Ewansiha, J.U., Garba, S.A., Mawak, J.D., Oyewole, O.A., 2012. Antimicrobial activity of Cymbopogon Citratus (lemon grass) and it's phytochemical properties. Frontiers Sci. 2, 214-220.

Figueirinha, A., Paranhos, A., Perez-Alonso, J.J., Santos-Buelga, C., Batista, M.T., 2008. Cymbopogon citratus leaves: characterization of flavonoids by HPLC-PDA-ESI/ MS/MS and an approach to their potential as a source of bioactive polyphenols. Food Chem. 110, 718-728.

Franck, C., Baetens, M., Lammertyn, J., Scheerlinck, N., Davey, M.W., Nicolai, B.M., 2003. Ascorbic acid mapping to study core breakdown development in "Conference" pears. Postharvest Biol. Technol. 30, 133-142.

Gioti, E., Fiamegos, Y., Skalkos, D., Stalikas, C., 2009. Antioxidant activity and bioactive componentes of the aerial parts of Hypericum perforatum L. from Epirus. Greece. Food Chem. 117, 398-404.

Govindarajan, R., Rastogi, S., Vijayakumar, M., Rawat, A.K.S., Shirwaikar, A., Mehrotra, S., Pushpangadam, P., 2003. Studies on antioxidant activities of Desmodium gangetium. Biol. Pharmaceut. Bull. 26, 1424-1427.

Gurib-Fakim, A., 2006. Medicinal plants: traditions of yesterday and drugs of tomorrow. Mol. Aspects Med. 27, 1-93. 
Harborne, J.B., 1998. Phytochemical methods: a guide to modern techniques of plant analysis, third ed. Chapman and Hall, London.

Kennedy, D.O., Wightrman, E.L., 2011. Herbal extracts and phytochemicals: plant secondary metabolites and the enhancement of human brain function. Adv. Nutr. 2, 35-50.

Khan, R.A., Khan, M.R., Sahreen, S., Ahmed, M., 2012. Evaluation of phenolic contents and antioxidant activity of various solvent extracts of Sonchus asper (L.) Hill. Chem. Central J. 6, 1-7.

Lulekal, E., Kelbessa, E., Bekele, T., Yineger, H., 2008. An ethnobotanical study of medicinal plants in Mana Angetu District, southeastern Ethiopia. J. Ethnobiol. Ethnomed. 4, 10.

Matasyoh, J.C., Wagara, I.N., Nakavuma, J.L., Kiburai, A.M., 2011. Chemical composition of Cymbopogon citratus essential oil and its effect on mycotoxigenicAspergillus species. Afr. J. Food Sci. 5, 138-142.

Mirghani, M.E.S., Liyana, Y., Parveen, J., 2012. Bioactivity analysis of lemongrass (Cymbopogan citratus) essential oil. Int. Food Res. J. 19, 569-575.

Molan, A.L., Liu, Z., De, S., 2009. Effect of pine bark (Pinus radiata) extracts on sporulation of coccidian oocysts. Folia Parasitol. 56, 1-5.

Moshi, M.J., Otieno, D.F., Weisheit, A., 2012. Ethnomedicine of the Kagera Region, North Western Tanzania. Part 3: plants used in traditional medicine in Kikuku village, Muleba District. J. Ethnobiol. Ethnomed. 8, 1-11.

Nema, R., Jain, P., Khare, S., Pradhan, A., Gupta, A., Singh, D., 2012. Antibacterial and antifungal activity of Terminalia Arjuna leaves extract with special reference to flavonoids. Basic Res. J. Med. Clin. Sci. 1, 63-65.

Oloyede, O.I., 2009. Chemical profile and antimicrobial activity of Cymbopogon citratus leaves. J. Nat. Prod. 2, 98-103.

Pereira, R.P., Fachinetto, R., Prestes, A.D., Puntel, R.L., da Silva, G.N.S., Heinzmann, B.M., Boschetti, T.K., Athayde, M.L., Burger, M.E., Morel, A.F., Morsch, V.M., Rocha, J.B.T., 2009. Antioxidant effects of different extracts from Melissa officinalis, Matricaria recutita and Cymbopogon citratus. Neurochem. Res. 34, 973-983.

Ronald, L., Wu, X., Schaich, K., 2005. Standardized methods for the determination of antioxidant capacity and phenolics in foods and dietary supplements. J. Agric. Food Chem. 53, 4291-4302.

Ruch, R.J., Cheng, S.J., Klaunig, J.E., 1989. Prevention of cytotoxicity and inhibition of intracellular communication by antioxidant catechins isolated from Chinese green tea. Carcinogenesis 10, 1003-1008.

Schneider, G., 1976. Zur Bestimmung der Gerbstoffe mit Casein. Arch. Pharm. 309, 38-44.

Schoeman, M.C., Cotterill, F.P.D., Taylor, P.J., Monadjem, A., 2013. Using potential distributions to explore environmental correlates of bat species richness in southern Africa: effects of model selection and taxonomy. Cur. Zool. 59, 279- 293.

Sessou, F., Farougou, S., Kaneho, S., Djenonti, S., Alitonou, G.A., Azokpota, P., Youssao, I., Sohounhlou, D., 2012. Bioefficacy of Cymbopogon citratus essential oil against foodborne pathogens in culture medium and in traditional cheese wagashi produced in Benin. Int. Res. J. Microbiol. 3, 406-415.

Silva, J.R.A., Ramos, A.S., Machado, M., Moura, D.F., Neto, Z., Cavalheiro, M.M.C., Figueiredo, P., Rosário, V.E., Amaral, A.C.F., Lopes, D., 2011. A review of antimalarial plants used in traditional medicine in communities in Portuguese-speaking countries: Brazil, Mozambique, Cape Verde, Guinea- Bissau, São Tomé and Príncipe and Angola. Mem. Inst. Oswaldo Cruz 106, 142-157.

Sofowara, A.E., 1993. Medicinal plants and traditional medicine in

Africa, vol. 2. Spectrum Books Ltd., Ibadan, Nigeria.

Tapia, A., Cheel, J., Theoduloz, C., Rodriguez, J., Schmeda-Hirschmann, G., Gerth, A., Wilken, D., Jordan, M., Jimenez-Gonzalez, E., GomezKosky, R., Mendoza, E.Q., 2007. Free radical scavengers from Cymbopogon citratus (DC.) stapf plants cultivated in bioreactors by the temporary immersion (TIS) principle. Z. Naturforsch. C. 62, 447-457.

Trease, G.E., Evans, W.C., 1989. Textbook of Pharmacognosy, twelfth ed. Balliere Tindall, London.
Vinha, A.F., Soares, M.O., Castro, A., Santos, A., Oliveira, M.B.P.P., Machado, M., 2012. Phytochemical characterization and radical scavenging activity of aqueous extracts of medicinal plants from Portugal. Eur. J. Med. Plants. 2, 335-347.

Xu, B.J., Chang, S.K., 2007. A comparative study on phenolic profiles and antioxidant activities of legumes as affected by extraction solvents. J. Food Sci. 72, S159-S166.

Yadav, R.N.S., Agarwala, M., 2011. Phytochemical analysis of some medicinal plants.

J. Phytol. 3, 10-14.

Zhishen, J., Mengcheng, T., Jianming, W., 1999. The determination of flavonoidcontents in mulberry and their scavenging effects on superoxide radicals. Food Chem. 64, 555-559. 